\title{
PERAN SEKTOR PARIWISATA PADA PERTUMBUHAN EKONOMI KABUPATEN/KOTA DI JAWA BARAT
}

\author{
Helmi Aliansyah ${ }^{1}$ \\ Wawan Hermawan' \\ Universitas Padjadjaran
}

\begin{abstract}
The tourism sector is a sector that is experiencing rapid growth in Indonesia, as well as in West Java Province. This research aims to prove that tourism sector affect economic growth in West Java. This research uses tourist arrival, government spending on tourism, number of hotel rooms, and number of restaurants as a proxy of tourism sector, while the ratio of agricultural sector of GDP is a control variable. The method used in this research is Generalized Least Squaress (GLS) by using panel data in 2012-2017 and 23 districts/city in West Java Province. The result of this study indicate that the number of hotel rooms, number of restaurants, government expenditure in the tourism sector, and the number of tourists has a positive impact on economic growth.
\end{abstract}

Keywords: economic growth; tourism sector; government spending; Generalized Least Squares (GLS); panel data; Jawa Barat

\begin{abstract}
ABSTRAK
Sektor Pariwisata merupakan sektor yang sedang mengalami pertumbuhan pesat di Indonesia, demikian juga di Provinsi Jawa Barat. Penelitian ini bertujuan untuk melihat apakah terdapat pengaruh sektor pariwisata pada pertumbuhan ekonomi di Jawa Barat. Penelitian ini menggunakan data jumlah wisatawan, pengeluaran pemerintah sektor pariwisata, jumlah kamar hotel, dan jumlah restoran/rumah makan sebagai proyeksi sektor pariwisata, sedangkan rasio sektor pertanian pada PDRB sebagai variabel kontrol. Metode yang digunakan adalah Generalized Least Squuare (GLS) dengan data panel pada periode 2012-2017 dan 23 Kabupaten/Kota di Jawa Barat. Hasil penelitian menunjukkan bahwa jumlah kamar hotel, jumlah rumah makan/restoran, pengeluaran pemerintah sektor pariwisata, dan jumlah wisatawan berpengaruh positif terhadap pertumbuhan ekonomi.
\end{abstract}

Kata kunci: pertumbuhan ekonomi; sektor pariwisata; belanja pemerintah; Generalized Least Squares (GLS); panel data; Jawa Barat

\section{PENDAHULUAN}

Indonesia merupakan negara kepulauan terbesar di dunia. Menurut Kementerian Dalam Negeri, pada tahun 2007-2008 terdapat 13.466 pulau yang sudah diverifikasi yang kemudian dikirimkan ke PBB untuk mendapatkan pengakuan formal. Dengan sekian banyak pulau tersebut, Indonesia berpotensi untuk menjadi destinasi wisata.

Bagi negara yang sedang berkembang dan memiliki kekayaan alam seperti Indonesia, industri pariwisata dapat dikatakan sebagai medium pembangunan ekonomi yang tidak memerlukan investasi terlalu besar. Daya tarik wisata alam dan budaya yang merupakan salah satu modal utama untuk pengembangan pariwisata; hal tersebut sudah tersedia bagi Indonesia. Oleh karenanya, ada peluang besar bagi Indonesia untuk menarik lebih banyak konsumen dari

\footnotetext{
1 helmi_hunt@hotmail.com

2 w.hermawan@unpad.ac.id
} 


\section{0| Bina Ekonomi}

segmen pasar pariwisata yang pada umumnya berasal dari negara-negara berpendapatan tinggi atau negara maju.

Undang-undang Nomor 10 tahun 2009 Pasal 14 menyebutkan bahwa sektor pariwisata meliputi beberapa usaha pariwisata yaitu: daya tarik wisata; kawasan pariwisata; jasa transportasi wisata; jasa perjalanan wisata; jasa makanan dan minuman; penyediaan akomodasi; penyelenggaraan pertemuan, perjalanan insentif, konferensi, dan pameran; jasa informasi pariwisata; jasa konsultan pariwisata; jasa pramuwisata; wisata tirta; dan spa. Pariwisata merupakan industri jasa yang memiliki mekanisme pengaturan yang kompleks karena mencakup pengaturan pergerakan wisatawan dari daerah atau negara asal ke daerah tujuan wisata, hingga kembali ke negara asalnya yang melibatkan berbagai komponen seperti biro perjalanan, pemandu wisata (guide), tour operator, akomodasi, restoran, artshop, moneychanger, transportasi, dan yang lainnya. Pariwisata juga menawarkan jenis produk dan wisata yang beragam, mulai dari wisata alam, wisata budaya, wisata sejarah, wisata buatan, hingga beragam wisata minat khusus. Wahab (2003) menyebut pariwisata adalah salah satu jenis industri baru yang mampu menghasilkan pertumbuhan ekonomi, yang cepat dalam penyediaan lapangan kerja, yang mampu meningkatkan standar hidup serta memiliki potensi menstimulasi sektor-sektor produktif lainnya. Selanjutnya sebagai sektor yang kompleks, Wahab (2003) juga mengikutsertakan industri-industri klasik seperti industri kerajinan tangan dan cinderamata. Penginapan dan transportasi secara ekonomis juga dipandang sebagai bagian dari sektor pariwisata (Wahab, 2003). Hal ini memberikan gambaran bahwa pariwisata merupakan industri yang memberikan dampak atas perekonomian, memberikan stimulus atas peningkatan pertumbuhan ekonomi melalui berbagai sektor yang terkait (Arghutashvili dan Tbilisi, 2018).

Sektor pariwisata memberi dampak yang sangat besar bagi masyarakat, terutama masyarakat yang berada di kawasan atau lokasi yang menjadi tujuan wisata. Salah satu program perencanaan pembangunan yang menjadi perhatian pemerintah daerah adalah pengembangan sektor pariwisata karena menganggap bahwa sektor pariwisata adalah salah satu sektor strategis dalam pengembangan perekonomian daerah sesuai dengan potensi yang mereka miliki.

Pariwisata merupakan salah satu sektor pembangunan yang saat ini sedang dikembangkan oleh pemerintah, karena pariwisata dianggap mempunyai peran yang sangat penting dalam pembangunan Indonesia khususnya sebagai salah satu sektor pendapatan daerah maupun negara. Pariwisata di Indonesia merupakan salah satu sektor ekonomi penting. Selain sebagai mesin penggerak ekonomi, pariwisata dianggap mampu mengurangi angka pengangguran. Dalam perekonomian nasional, pariwisata merupakan sektor yang diharapkan mampu meningkatkan pendapatan melalui penerimaan devisa.

Indonesia merupakan negara berkembang yang membutuhkan banyak devisa. Cadangan devisa negara digunakan untuk membeli barang dan jasa dari luar negeri, keperluan pembiayaan kegiatan perdagangan luar negeri, dan menjalankan roda pembangunan dan perekonomian.

Berbagai sektor ekonomi menjadi unggulan dalam penerimaan devisa, salah satunya adalah sektor pariwisata (lihat Tabel 1.).

Berdasarkan Tabel 1., devisa yang diterima Indonesia dari sektor pariwisata tiap tahunnya mengalami peningkatan. Pada tahun 2016 pariwisata menjadi penyumbang devisa terbesar nomor dua di Indonesia setelah Crude Palm Oil (CPO). Peningkatan jumlah wisatawan asing yang datang ke Indonesia berdampak pada peningkatan peneriman devisa pada jenis akomodasi pariwisata di Indonesia. Hal ini terjadi karena pemerintah Indonesia, khususnya Kementerian Pariwisata, melakukan strategi destinasi prioritas pada beberapa titik daerah atau 
obyek wisata di beberapa daerah, serta dukungan alokasi anggaran dan publikasi. Dengan demikian sektor pariwisata di Indonesia menjadi salah satu sektor sumber devisa negara yang dianggap penting dibandingkan dengan sektor lapangan usaha lain.

Tabel 1. Penerimaan Devisa Berdasarkan Sektor Lapangan Usaha (juta USD)

\begin{tabular}{|l|l|r|r|r|r|}
\hline \multirow{2}{*}{ No } & \multirow{2}{*}{ Jenis Lapangan Usaha } & \multicolumn{4}{|c|}{ Tahun } \\
\cline { 3 - 6 } & & 2013 & 2014 & \multicolumn{1}{c|}{2015} & \multicolumn{1}{c|}{2016} \\
\hline 1 & Migas & 32.633 & 30.318 & 18.57 & 13.105 \\
\hline 2 & BatuBara & 22.759 & 18.7 & 14.72 & 12.898 \\
\hline 3 & CPO & 16.787 & 18.62 & 16.43 & 15.965 \\
\hline 4 & Pariwisata & 10.054 & 11.166 & 12.225 & 13.57 \\
\hline 5 & Karetolahan & 6.706 & 6.259 & 3.564 & 3.242 \\
\hline 6 & Pakaian jadi & 6.216 & 7.450 & 6.41 & 6.229 \\
\hline 7 & Alat listrik & 5.104 & 7.021 & 4.51 & 4.561 \\
\hline 8 & Bahan kimia & 4.124 & 6.486 & 3.174 & 3.700 \\
\hline 9 & Kertas & 3.723 & 5.379 & 3.546 & 4.032 \\
\hline 10 & Tekstil & 1.948 & 3.853 & 1.927 & 1.848 \\
\hline 11 & Kayu olahan & 1.203 & 3.780 & 1.352 & 1.279 \\
\hline 12 & Perhiasan & 202 & 3.914 & 3.319 & 4.119 \\
\hline
\end{tabular}

Sumber: BPS dan Pusdatin Kemenpar Tahun 2018

Jawa Barat memiliki kurang lebih 350 obyek wisata. Bahkan setiap obyek wisata memiliki lebih dari satu potensi, yakni sumber daya alam mulai dari gunung, rimba, laut, air, pantai dan seni budaya. Kelima potensi alam dan satu hasil budaya budaya lokal menjadi inti bisnis pariwisata di Jawa Barat. Melalui kelima obyek wisata tersebut, sudah seharusnya Pendapatan Asli Daerah (PAD) bertambah mulai dari retribusi, dan pajak restoran, hotel, dan fasilitas penunjang lainnya.

Provinsi Jawa Barat sendiri merupakan daerah yang masih berkembang dimana segala sektornya masih belum bisa dikatakan telah maju, meskipun Provinsi Jawa Barat memiliki sektor unggulan, yakni mengandalkan sektor industri pengolahan. Sektor pariwisata sendiri dapat dikatakan belum mampu dikembangkan secara maksimal oleh Pemerintah Provinsi Jawa Barat, pemanfaatan potensi sektor pariwisata belum mampu diolah secara maksimal, sehingga masih sangat jauh untuk dibandingkan dengan pariwisata yang terdapat di daerah-daerah lain di Indonesia. Hal-hal tersebut perlu menjadi perhatian khusus bagi pemerintah daerah.

Dengan dikeluarkannnya Undang-Undang Nomor 32 Tahun 2004 tentang Pemerintahan Daerah dan Undang-undang Nomor 33 Tahun 2004 tentang Perimbangan Keuangan Pusat dan Daerah, ada peluang besar bagi daerah untuk mengelola sumber daya alam yang dimiliki agar dapat memberikan hasil yang optimal. Setiap pemerintah daerah berupaya keras meningkatkan perekonomian daerahnya sendiri termasuk meningkatkan perolehan PAD. Di samping pengelolaan terhadap sumber PAD yang sudah ada perlu ditingkatkan, daerah juga harus selalu kreatif dan inovatif dalam mencari dan mengembangkan potensi sumber PAD, sehingga semakin banyak sumber-sumber PAD daerah yang dapat dipergunakan untuk membangun daerahnya. Menurut Undang-undang nomor 22 tahun 1999 pendapatan asli daerah (PAD) terdiri atas empat komponen, yaitu: hasil pajak daerah, hasil retribusi daerah, hasil perusahaan milik daerah dan hasil pengelolaan kekayaan daerah yang dipisahkan, dan lain-lain pendapatan asli daerah yang sah. 


\section{2| Bina Ekonomi}

Salah satu faktor penting dari sektor pariwisata adalah kunjungan wisatawan, baik wisatawan asing maupun wisatawan nusantara. Data menunjukkan, jumlah wisatawan yang berkunjung ke Jawa Barat dari tahun 2012 sampai 2016 selalu mengalami kenaikan (lihat Tabel 2.). Namun jika dilihat asal wisatawan, pada tahun 2013 terjadi penurunan jumlah wisatawan mancanegara sebesar 5,82\%. Pada tahun 2016 merupakan pertumbuhan jumlah wisatawan mancanegara terbesar, mencapai 118,39\%. Pada tahun 2015 jumlah wisatawan mengalami pertumbuhan yang paling pesat, yaitu sebesar $17 \%$.

Tabel 2. Jumlah Wisatawan di Provinsi Jawa Barat 2012-2016

\begin{tabular}{|c|c|c|c|c|}
\hline \multirow{2}{*}{ Tahun } & \multicolumn{2}{|c|}{ Wisatawan } & \multirow{2}{*}{ Jumlah } & \multirow{2}{*}{ Pertumbuhan } \\
\cline { 2 - 3 } & Mancanegara & Domestik & & - \\
\hline 2012 & 1.905 .378 & 42.758 .063 & 44.663 .441 & $4 \%$ \\
\hline 2013 & 1.794 .401 & 45.536 .179 & 47.330 .580 & $7 \%$ \\
\hline 2014 & 1.962 .639 & 47.992 .088 & 49.954 .727 & $17 \%$ \\
\hline 2015 & 2.027 .629 & 56.334 .706 & 58.362 .335 & $13 \%$ \\
\hline 2016 & 4.428 .094 & 58.728 .666 & 63.156 .760 & \\
\hline
\end{tabular}

Sumber: Jawa Barat dalam Angka, Tahun 2013-2017

Jika dilihat menurut wilayah kota/kabupaten, jumlah wisatawan di Jawa Barat pada tahun 2012 sampai 2017 cenderung berfluktuasi dan terlihat ada ketimpangan penyebarannya (lihat Gambar 1.). Kabupaten Bogor, Kabupaten Bandung, Kota Bogor dan Kota Bandung menjadi wilayah yang paling banyak dikunjungi wisatawan, dengan perbedaan jumlah kunjungan yang jauh lebih besar dibanding kabupaten/kota lain. Sedangkan Kota Bekasi, Kota Cimahi dan Kota Banjar merupakan wilayah dengan jumlah wisatawan yang sangat rendah. Pada tahun 2017, terjadi lonjakan jumlah wisatawan yang besar di Kabupaten Purwakarta, tidak terprediksi dari kecenderungan yang terjadi pada tahun-tahun sebelumnya.

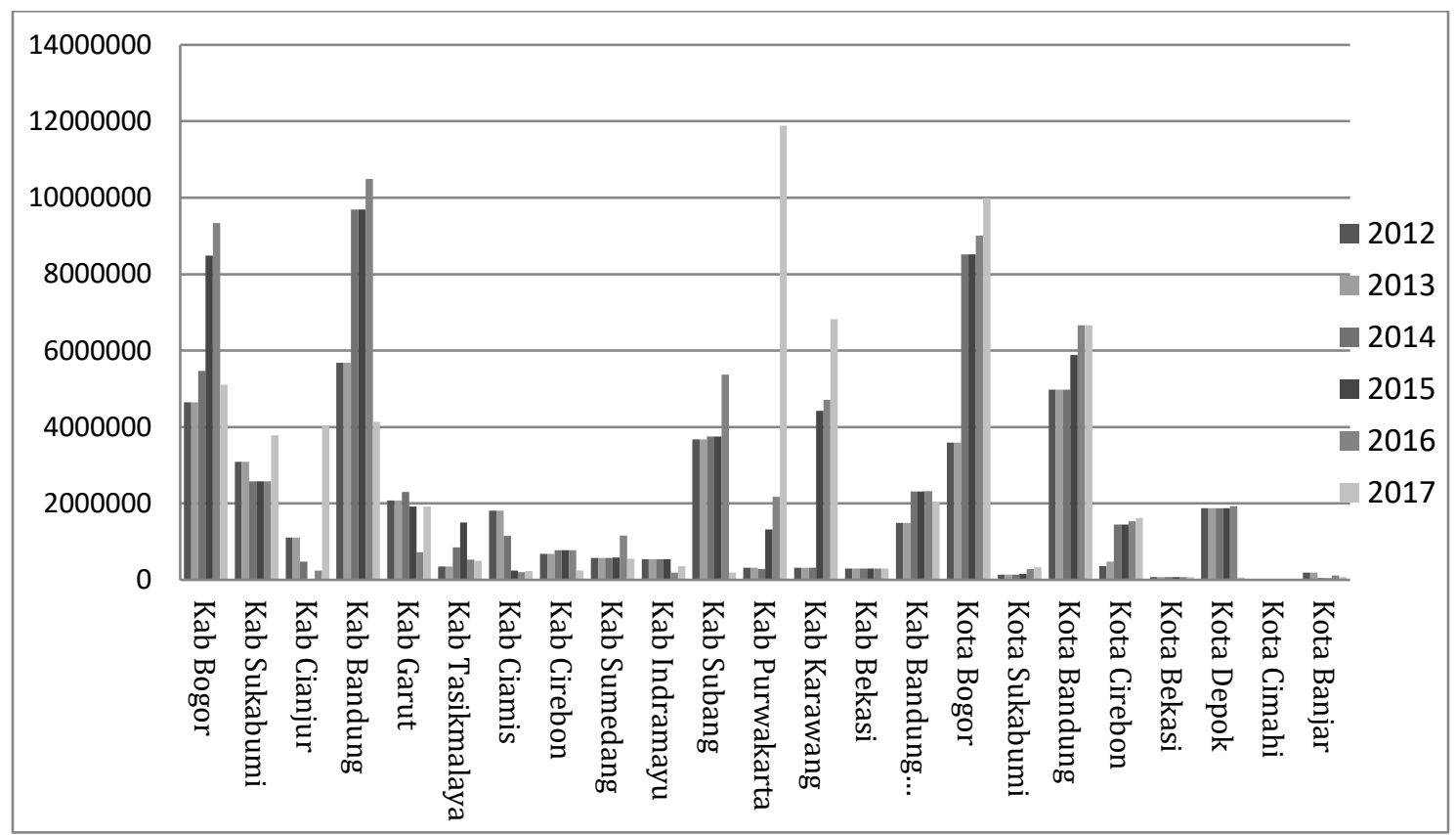

Sumber: Jawa Barat dalam Angka, Tahun 2013-2018

\section{Gambar 1. Jumlah Wisatawan di Kabupaten/Kota Jawa Barat 2012-2017 (orang)}

Sejak diberlakukannya Undang-undang nomor 32 tahun 2004 tentang penyerahan wewenang pemerintahan oleh pemerintah pusat kepada daerah otonom, penyelenggaraan pemerintahan daerah dilakukan oleh Pemerintah Daerah dan Dewan Perwakilan Rakyat Daerah 
(DPRD) dengan menganut asas otonomi serta tugas pembantuan dan prinsip otonomi yang seluas-luasnya. Pemerintah pusat tidak lagi mengatur, mendominasi pemerintah dan masyarakat daerah. Peran pemerintah pusat dalam konteks desentralisasi adalah melakukan supervisi, memantau, mengawasi dan mengevaluasi pelaksanaan otonomi daerah. Dalam konteks otonomi daerah, pendapatan daerah menjadi penting sebagai sumber pembiayaan.

Banyaknya kunjungan wisatawan ke Jawa Barat merupakan salah satu sumber Pendapatan Asli Daerah (PAD). Setiap kunjungan ke obyek wisata, Pemerintah Daerah akan memungut pembayaran atas pelayanan tempat pariwisata (retribusi). Selain itu, PAD juga didapatkan dari pendapatan daerah lain seperti pajak restoran, hotel, dan fasilitas penunjang lainnya. Oleh karena itu, PAD sangat tergantung pada pertumbuhan ekonomi, terutama dari sektor-sektor tersebut.

Sektor pariwisata merupakan sektor yang dianggap penting dalam meningkatkan devisa negara dan untuk pembangunan perekonomian daerah. Berdasarkan data jumlah wisatawan pada tiap kabupaten/kota masih banyak daerah yang mengalami penurunan jumlah wisatawan, dengan demikian sektor pariwisata daerah belum dapat dimaksimalkan untuk meningkatkan PDRB Jawa Barat. Oleh karena itu perlu diadakan studi mengenai pengaruh sektor pariwisata terhadap pertumbuhan ekonomi daerah di kabupaten/kota Jawa Barat agar memperoleh jawaban atas permasalahan-permasalahan yang ada. Keberhasilan pengembangan sektor pariwisata akan meningkatkan perannya dalam membangun daerah, sebab sektor pariwisata merupakan komponen penting dalam meningkatkan penerimaan daerah. Pengembangan sektor pariwisata dapat dilaksanakan dengan memerhatikan faktor-faktor yang mendukungnya, seperti: jumlah wisatawan domestik maupun asing, jumlah kamar hotel, jumlah restoran/rumah makan, dan pengeluaran pemerintah sektor pariwisata.

Berdasarkan latar belakang di atas, maka tujuan dari penelitian ini mencakup: pertama untuk mengetahui pengaruh sektor pariwisata terhadap pertumbuhan ekonomi di kabupaten/kota Jawa Barat dan kedua untuk mengetahui seberapa besar pengaruh sektor pariwisata terhadap pertumbuhan ekonomi di Kabupaten/Kota Jawa Barat.

\section{TINJAUAN PUSTAKA}

Tujuan perekonomian suatu negara adalah untuk meningkatkan kesejahteraan masyarakat yang ditandai oleh adanya pertumbuhan ekonomi. Pertumbuhan ekonomi merupakan salah satu parameter dari keberhasilan suatu negara dalam proses pembangunan. Untuk mencapai pertumbuhan ekonomi tidak lepas dari peran pemerintah sebagai pemberi kebijakan untuk meningkatkan pertumbuhan ekonomi.

Pertumbuhan ekonomi ditandai dengan peningkatan Produk Domestik Bruto (PDB) riil untuk tingkat nasional atau Produk Domestik Regional Bruto (PDRB) untuk tingkat daerah yang merupakan pendapatan total atau pengeluaran total atas output barang dan jasa dalam suatu periode tertentu. Kebijakan ekonomi yang dapat menaikkan tingkat pertumbuhan output perlu dilakukan karena dipandang sebagai salah satu syarat yang diperlukan untuk memperbaiki kesejahteraan masyarakat di negara berkembang.

Menurut Sukirno (1997) pertumbuhan dan pembangunan ekonomi memiliki definisi yang berbeda, keduanya memang menerangkan mengenai perkembangan ekonomi yang berlaku, 


\section{4| Bina Ekonomi}

tetapi biasanya mereka digunakan dalam konteks yang berbeda. Pertumbuhan selalu digunakan sebagai ungkapan umum yang menggambarkan tingkat perkembangan suatu negara, yang diukur melalui pertambahan atau persentasi pertambahan dari pendapatan nasional riil. Istilah pembangunan ekonomi biasanya dikaitkan dengan perkembangan ekonomi negara-negara berkembang.

Belanja modal adalah bagian dari pengeluaran atau belanja pemerintah yang berada pada bagian belanja langsung. Kementerian Keuangan (2016) mendefinisikan belanja modal sebagai pengeluaran anggaran yang digunakan dalam rangka memperoleh atau menambah aset tetap dan aset lainnya yang memberi manfaat lebih dari satu periode akuntansi serta melebihi batasan minimal kapitalisasi aset tetap atau aset lainnya yang ditetapkan pemerintah. Aset tetap tersebut dipergunakan untuk operasional kegiatan sehari-hari suatu satuan kerja bukan untuk dijual.

Secara garis besar pengertian belanja modal adalah pengeluaran yang dilakukan dalam rangka pembentukan modal yang sifatnya menambah aset tetap/inventaris yang memberikan manfaat lebih dari satu periode, termasuk di dalamnya pengeluaran untuk biaya pemeliharaan yang sifatnya menjaga atau menambah manfaat, serta meningkatkan kuantitas dan kualitas aset. Belanja modal dapat dibagi ke dalam lima kategori utama, yaitu: belanja modal tanah, belanja modal peralatan dan mesin, belanja modal gedung dan bangunan, belanja modal jalan irigasi dan jaringan, serta belanja modal fisik lainnya. Belanja modal tersebut menciptakan faktor-faktor pendukung seperti akses jalan, sarana kesehatan dan pendidikan, dan modal lainnya yang dapat mendukung peningkatan produktivitas yang akan meningkatkan pertumbuhan ekonomi.

Pengertian Belanja Modal di atas diimplementasikan oleh Ige \& Odularu (2008) dan Ardana (2017) sebagai salah satu variabel yang mempengaruhi pertumbuhan ekonomi dalam konteks pariwisata dan menunjukkan tingkat pengaruh yang signifikan. Belanja modal yang dimaksud adalah belanja modal pemerintah untuk urusan pariwisata yang dikeluarkan melalui Anggaran Pendapatan dan Belanja Daerah masing-masing.

Analisis atas pengaruh beberapa variabel sektor pariwisata terhadap PDB dilakukan oleh beberapa penulis, antara lain Ige \& Odularu (2008) di Afrika; Amnar, Muhammad dan Syechalad (2017) di Kota Sabang; Rediteani dan Setiawina (2018) di Kota Denpasar; Ardana (2017) dalam konteks negara-negara anggota APEC; serta, Pertiwi, Budhi, dan Saskara (2017) di wilayah Sarbagita, Provinsi Bali.

Penelitian yang dilakukan oleh Ige \& Odularu (2008) bertujuan untuk menyelidiki pengaruh dari variabel-variabel: PDB riil per kapita tahun sebelumnya, jumlah kedatangan wisatawan, keterbukaan ekonomi, pengeluaran pemerintah, investasi domestik bruto, indeks harga konsumen (inflasi), terhadap PDB riil per kapita. Hasil penelitian mereka menunjukkan bahwa seluruh variabel bebas yang digunakan berpengaruh terhadap PDB riil per kapita negaranegara di Afrika Barat pada tahun 2000-2004. Dengan kata lain, sektor pariwisata (dalam hal ini diwakili oleh jumlah kedatangan wisatawan) berperan dalam pertumbuhan perekonomian negara-negara di Afrika Barat.

Penelitian Amnar, Muhammad, dan Syechalad (2017) bertujuan untuk menyelidiki pengaruh jumlah wisatawan mancanegara, jumlah wisatawan nusantara, jumlah lokasi wisata, dan jumlah kamar hotel, baik secara parsial maupun secara keseluruhan terhadap pertumbuhan ekonomi Kota Sabang. Hasil penelitian mereka menunjukkan bahwa semua variabel bebas yang digunakan berpengaruh positif dan signifikan secara bersama-sama maupun parsial terhadap pertumbuhan ekonomi regional Kota Sabang (Amnar, Muhammad, dan Syechalad, 2017). 
Rediteani dan Setiawina (2018) meneliti pengaruh variabel-variabel: jumlah kunjungan wisatawan, lama tingal dan tingkat hunian hotel terhadap pajak hotel restoran dan pertumbuhan ekonomi. Dalam penelitian mereka, Rediteani dan Setiawina (2018) menggunakan teknik analisis jalur (path analysis) dan uji Sobel. Hasil penelitian mereka menunjukkan bahwa jumlah kunjungan wisatawan dan lama tinggal berpengaruh langsung dan signifikan terhadap pajak hotel dan restoran, sedangkan tingkat hunian hotel tidak berpengaruh langsung dan signifikan terhadap pajak hotel dan restoran. Jumlah kunjungan wisatawan tidak berpengaruh langsung terhadap pertumbuhan ekonomi, sedangkan lama tinggal, tingkat hunian hotel, dan pajak hotel restoran berpengaruh langsung dan signifikan terhadap pertumbuhan ekonomi. Pajak hotel dan restoran merupakan variabel intervening jumlah kunjungan wisatawan terhadap pertumbuhan ekonomi.

Ardana (2017) menganalisis pengaruh sektor pariwisata pada pertumbuhan ekonomi negara-negara anggota APEC, untuk periode 2010-2015. Hasil penelitian Ardana (2017) menunjukkan bahwa dampak pariwisata pada pertumbuhan ekonomi di wilayah APEC dipengaruhi oleh tiga variabel, yaitu: pengeluaran pemerintah di sektor pariwisata, investasi di sektor pariwisata, serta total pengeluaran wisatawan domestik dan internasional; dan ketiga variabel tersebut mampu memberikan dampak positif pada pertumbuhan ekonomi.

Pertiwi, Budhi, dan Saskara (2017) meneliti pengaruh jumlah kunjungan wisatawan, tingkat hunian kamar, dan jumlah restoran terhadap pajak hotel dan restoran dan PDRB kawasan Sarbagita di Provinsi Bali. Metode yang digunakan dalam penelitian ini adalah analisis jalur (path analysis). Hasil penelitian menunjukkan jumlah kunjungan wisatawan, tingkat hunian kamar, jumlah restoran berpengaruh positif dan signifikan terhadap pajak hotel dan restoran. Sementara itu, jumlah kunjungan wisatawan, tingkat hunian kamar dan jumlah restoran berpengaruh positif dan signifikan terhadap PDRB; sedangkan, pajak hotel dan restoran berpengaruh negatif terhadap PDRB. Kesimpulan lainnya adalah, variabel pajak hotel dan restoran bukan merupakan variabel yang memediasi pengaruh jumlah wisatwan, tingkat hunian kamar dan jumlah restoran terhadap PDRB.

Perekonomian ditunjukkan oleh pertumbuhan dari Produk Domestik Bruto riil yang terdiri dari 17 sektor, dimana sektor pertama merupakan sektor pertanian. Banyak literatur yang menunjukkan peran penting dari sektor pertanian terhadap perekonomian, dimana sebagai penyerap tenaga kerja ketiga terbesar dan sektor keempat kontribusi terbesar terhadap PDRB di Provinsi Jawa Barat tahun 2018. Banyak kabupaten di Provinsi Jawa Barat (terdiri dari 18 Kabupaten dan 9 Kota) masih mengandalkan sebagai sektor utama dalam penyerapan tenaga kerja dan kontribusi terhadap PDRB. Hal ini memberikan dasar atas pentingnya sektor pertanian sebagai variabel kontrol dalam mempengaruhi perekonomian. Beberapa peneliti yang menunjukkan pentingnya sektor pertanian terhadap perekonomian atau pertumbuhan perekonomian ditunjukkan oleh Sertoğlu, Kamil; Ugural, Sevin; Bekun, (2017) dan Ekine; Irene, Data, Onu; Catherine, (2018).

Berdasarkan literatur di atas, variabel Jumlah Wisatawan dapat memberikan gambaran atas pengaruhnya terhadap perekonomian. Variabel kontrol dari jumlah wisatawan dijelaskan oleh Pengeluaran Pemerintah untuk Sektor Wisata, Jumlah Rumah Makan, Jumlah Kamar Hotel dan Rasio dari PDRB Sektor Pertanian. 


\section{6| Bina Ekonomi}

\section{MODEL PENELITIAN}

Penelitian ini bertujuan untuk melihat bagaimana pengaruh sektor pariwisata terhadap pertumbuhan ekonomi. Selain itu juga untuk melihat bagaimana peran sektor pariwisata dalam kaitannya antara tingkat pengeluaran pemerintah dengan pertumbuhan ekonomi. Data yang digunakan dalam penelitian ini adalah data tahunan kabupaten/kota Jawa Barat selama periode 2012-2017.

Terdapat dua teknik analisis yang digunakan dalam penelitian ini. Pertama adalah deskriptif kualitatif, yaitu analisis yang dilakukan berdasarkan pada tinjauan literatur jurnal, working paper, artikel, buku dan hasil penelitian lainnya yang berhubungan dengan masalah yang diteliti. Kedua adalah analisis deskriptif kuantitatif, yaitu menggunakan model ekonometrika untuk menjelaskan hubungan antara variabel-variabel yang ingin diteliti. Penelitian ini menggunakan data 23 kabupaten/kota di Jawa Barat, periode yang dipilih adalah tahun 20122017.

Model yang digunakan dalam penelitian ini berdasarkan penelitian yang telah ditulis oleh Ige \& Odularu (2010), dengan menggunakan lima variabel, yaitu PDRB kabupaten/kota Jawa Barat, jumlah kedatangan wisatawan kabupaten/kota Jawa Barat, jumlah pengeluaran pemerintah sektor pariwisata, jumlah restoran/rumah makan di kabupaten/kota Jawa Barat, dan Jumlah kamar hotel di kabupaten/kota Jawa Barat. PDRB sebagai variabel dependen, dan variabel independen yaitu jumlah kedatangan wisatawan, pengeluaran pemerintah sektor pariwisata, jumlah restoran/rumah makan, dan jumlah kamar hotel. Model penelitian yang digunakan adalah sebagai berikut:

$$
\operatorname{LnPDRB}_{i t}=\alpha+\beta_{1} \operatorname{LnWIS}_{i t}+\beta_{2} \operatorname{LnGOVEX}_{i t}+\beta_{3} L n R M_{i t}+\beta_{4} L n K H_{i t}+\beta_{5} R P D R B P+e_{i t}
$$

PDRB adalah Produk Domestik Regional Bruto (PDRB) per-kabupaten/kota di Jawa Barat; WIS adalah jumlah kedatangan wisatawan di kabupaten/kota di Jawa Barat; GOVEX adalah pengeluaran pemerintah di sektor pariwisata di kabupaten/kota di Jawa Barat; RM adalah jumah restoran/rumah makan di kabupaten/kota di Jawa Barat; KH adalah jumlah kamar hotel di kabupaten/kota di Jawa Barat; dan, RPDRBP adalah rasio PDRB pertanian terhadap PDRB. Subscript untuk i menunjukkan kabupaten/kota di Provinsi Jawa Barat dan t menunjukkan tahun observasi. Semua variabel menggunakan bentuk logaritma natural, selain variabel RPDRBP yang dalam bentuk persen.

PDRB yang digunakan pada penelitian ini yaitu PDRB Atas Dasar Harga Konstan (ADHK). Wisatawan dalam penelitian ini adalah penggabungan antara data jumlah wisatawan mancanegara dan wisatawan nusantara menurut akomodasi dan obyek wisata pada masingmasing kabupaten/kota di Jawa Barat. Pengeluaran pemerintah sektor pariwisata dalam penelitian ini adalah rancangan pengeluaran pemerintah pada APBD yang terklasifikasi pada pembiayaan sektor pariwisata. Pengeluaran pemerintah sektor pariwisata terdapat pada APBD per urusan. Restoran/rumah makan dalam penelitian ini adalah banyaknya rumah makan dengan restoran penyedia hidangan dan minuman untuk umum pada masing-masing kabupaten/kota Jawa Barat. Kamar hotel dalam penelitian ini merupakan penggabungan antara jumlah kamar hotel berbintang dengan jumlah kamar hotel non-bintang pada masing-masing kabupaten/kota di Jawa barat. Rasio PDRB pertanian dalam penelitian ini adalah PDRB sektor pertanian yang tertera di PDRB ADHK tahun 2010 menurut lapangan usaha, dalam hal ini lapangan usaha pertanian, peternakan kehutanan dan perikanan. RPDRBP digunakan sebagai variabel kontrol dalam model penelitian ini. Variabel ini dianggap mampu meningkatkan tingkat kepercayaan 
estimasi model.

Pengujian untuk model dilakukan untuk Uji Chow atau uji untuk menentukan apakah pendekatan model yang digunakan adalah pooled least Squares atau dengan fixed effect. Untuk menentukan menggunakan pendekatan fixed effect atau random effect pada model, dilakukan uji Hausman. Uji t dilakukan untuk menguji apakah terdapat pengaruh antara variabel independen terhadap variabel dependen-nya; sementara itu, Uji F digunakan untuk mengetahui apakah variabel independen secara bersama-sama berpengaruh signifikan terhadap variabel dependen.

Uji Asumsi Klasik yang dilakukan ada tiga. Pertama, Heteroskedastisitas yang dilakukan untuk menguji varians dari error terms tidak konstan. Kedua, uji Multikolinieritas yang dilakukan untuk mengetahui apakah terjadi korelasi antara setiap variabel independen dari suatu model regresi. Ketiga, uji Otokorelasi dilakukan untuk melihat apakah terdapat hubungan antara error antar data time series.

\section{HASIL DAN PEMBAHASAN}

Pada bagian ini akan dipaparkan hasil dan pembahasan berupa analisis data dan analisis model yaitu berupa analisis ekonometrika, analisis statistik, dan analisis ekonomi. Analisis data merupakan penjabaran dari setiap variabel yang diteliti di wilayah yang menjadi objek penelitian, dari tahun 2012 sampai dengan 2017, yaitu variabel-variabel: PDRB, jumlah wisatawan, pengeluaran pemerintah sektor pariwisata, jumlah restoran/rumah makan, jumlah kamar hotel, dan rasio PDRB pertanian terhadap PDRB.

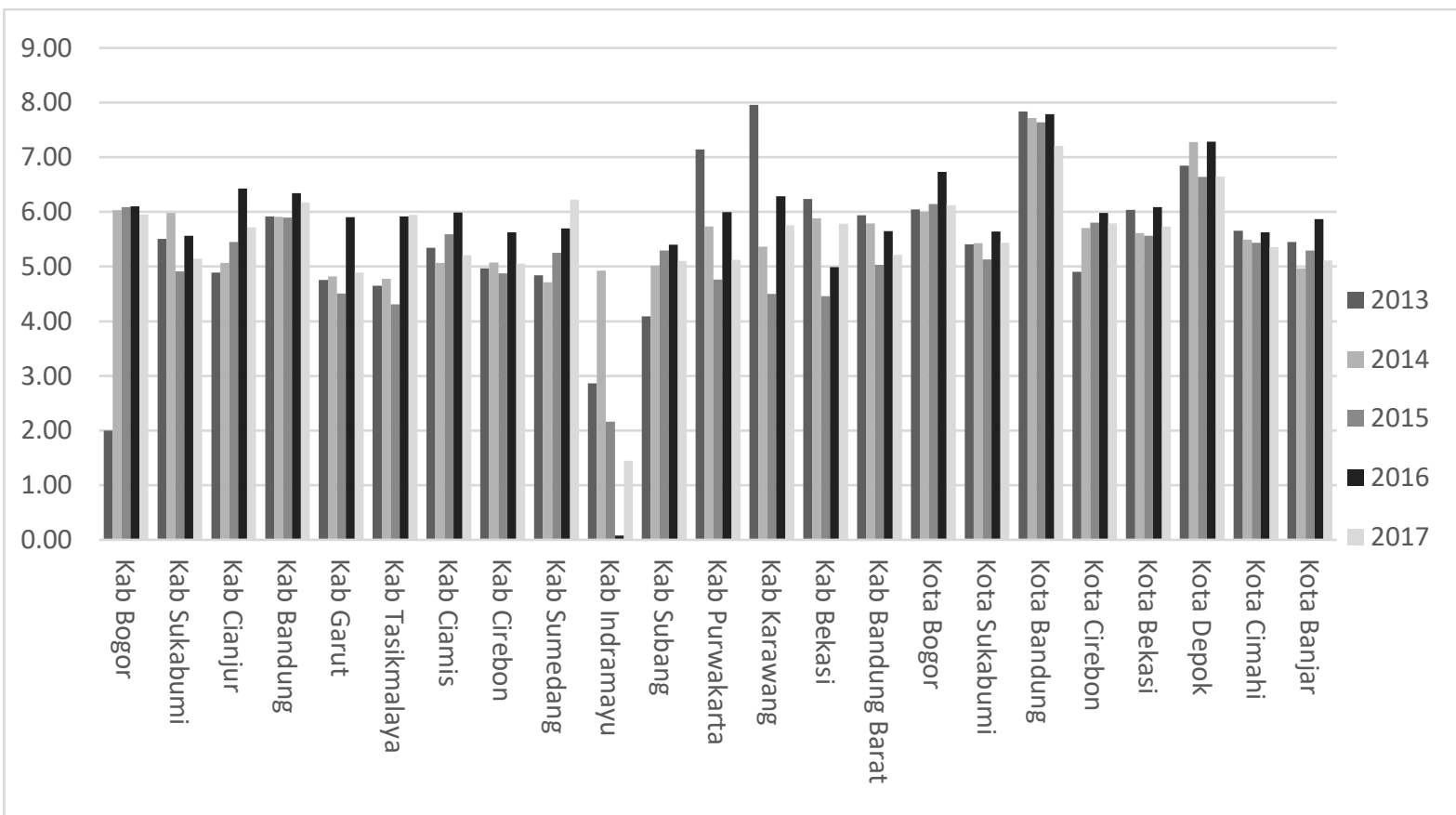

Sumber: Badan Pusat Statistik (BPS)

\section{Gambar 2. Laju Pertumbuhan PDRB ADHK Kabupaten/Kota di Jawa Barat Tahun 2012- 2017 (Persen)}

Pertumbuhan ekonomi kabupaten/kota di Jawa Barat yang digambarkan oleh Gambar 2. memperlihatkan kecenderungan penurunan, bahkan ada kabupaten/kota yang hampir tidak 


\section{8| Bina Ekonomi}

mengalami pertumbuhan ekonomi yaitu Kabupaten Indramayu pada tahun 2016. Secara keseluruhan, pada tahun 2014 pertumbuhan ekonomi adalah sebesar 5,88\%; sedangkan pada tahun 2015 adalah sebesar 5,33\% atau mengalami penurunan sebesar 0,55\% dari tahun sebelumnya. Pada tahun 2016 pertumbuhan ekonomi adalah sebesar 5,85\%, sedangkan pada tahun 2017 pertumbuhan ekonomi adalah sebesar 5,74\%, atau mengalami penurunan sebesar 0,11\% dari tahun sebelumnya. Hal ini mengindikasikan bahwa keadaan ekonomi kabupaten/kota di Jawa Barat sedang dalam kondisi yang kurang baik.

Gambar 3. memperlihatkan data jumlah wisatawan di kabupaten/kota di Jawa Barat dalam rentang waktu 2012 - 2017. Dari data terlihat bahwa jumlah wisatawan berfluktuasi dan sangat terlihat ketimpangan antar-kabupaten/kota. Terlihat bahwa Kabupaten Bogor, Kabupaten Bandung, Kota Bogor, dan Kota Bandung didatangi wisatawan dalam jumlah yang jauh lebih besar dibanding kabupaten/kota lain. Sedangkan jumlah wisatawan yang berkunjung ke Kota Bekasi, Kota Cimahi dan Kota Banjar paling sedikit di antara kabupaten/kota lain di provinsi itu. Pada tahun 2017 terjadi lonjakan jumlah wisatawan yang tidak terprediksi dari tahun-tahun sebelumnya di Kabupaten Purwakarta.

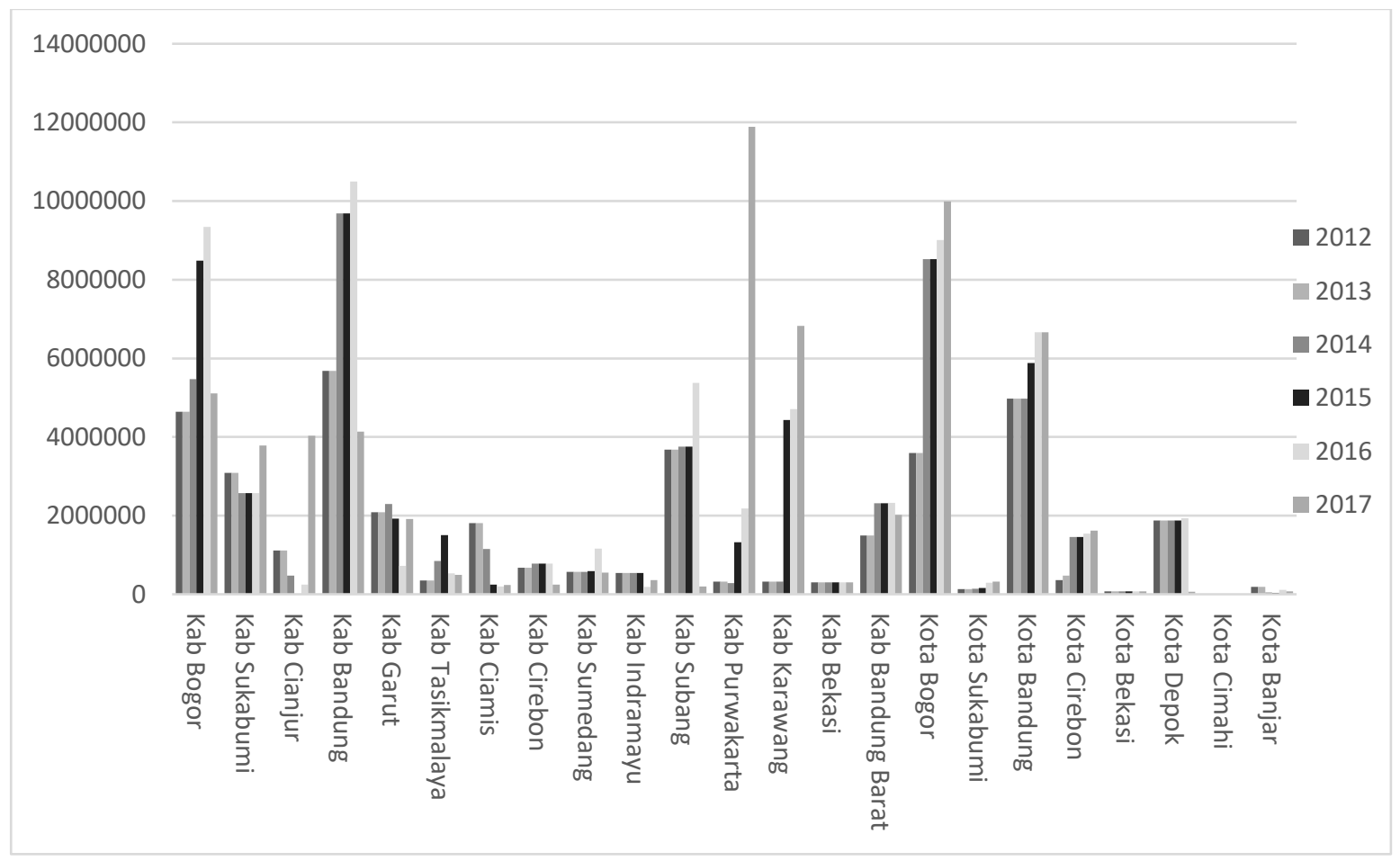

Sumber: Dinas Kebudayan dan Pariwisata

\section{Gambar 3. Jumlah Wisatawan Kabupaten/Kota di Jawa Barat Tahun 2012-2017 (orang)}

Gambar 4. yang menunjukkan jumlah pengeluaran pemerintah untuk sektor pariwisata di kabupaten/kota di Jawa Barat menunjukkan bahwa dalam rentang tahun 2012 - 2017 variabel tersebut mengalami peningkatan setiap tahunnya. Namun penyebaran pengeluaran pemerintah sektor pariwisata tidak merata untuk setiap kabupaten/kota. Terlihat bahwa Kota Bandung memiliki jumlah pengeluaran pemerintah sektor pariwisata tertinggi dibandingkan dengan kabupaten/kota lain di Jawa Barat. Sementara itu Kabupaten Karawang, Kota Cirebon, Kota Cimahi, dan Kota Banjar menjadi provinsi yang terendah dibandingkan dengan Kabupaten/Kota lainnya di Jawa Barat. 


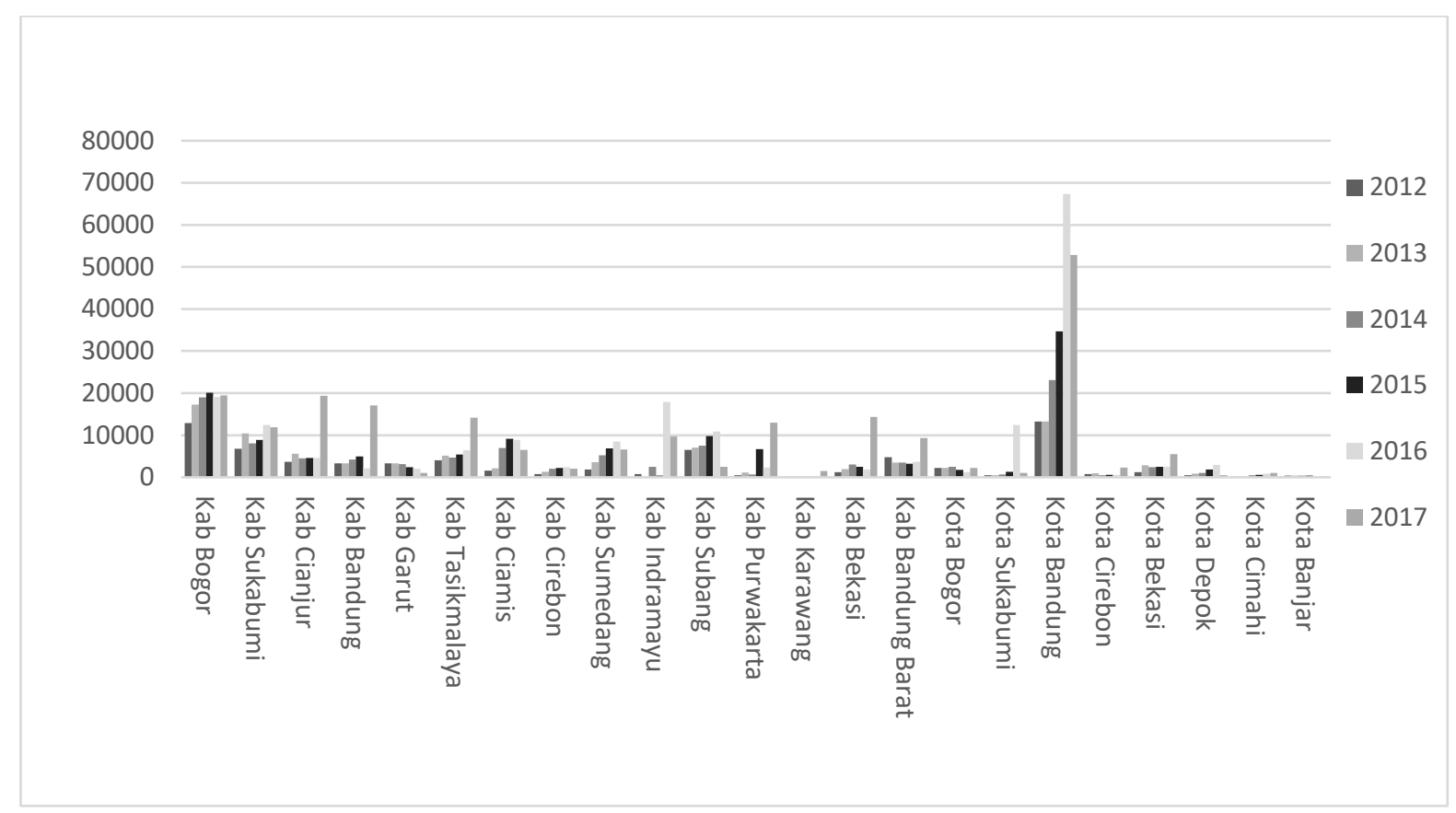

Sumber: Direktorat Jendral Perimbangan Keuangan (DJPK)

Gambar 4. Pengeluaran Pemerintah untuk Sektor Pariwisata Kabupaten/Kota di Jawa Barat Tahun 2012-2017 (Juta Rupiah)

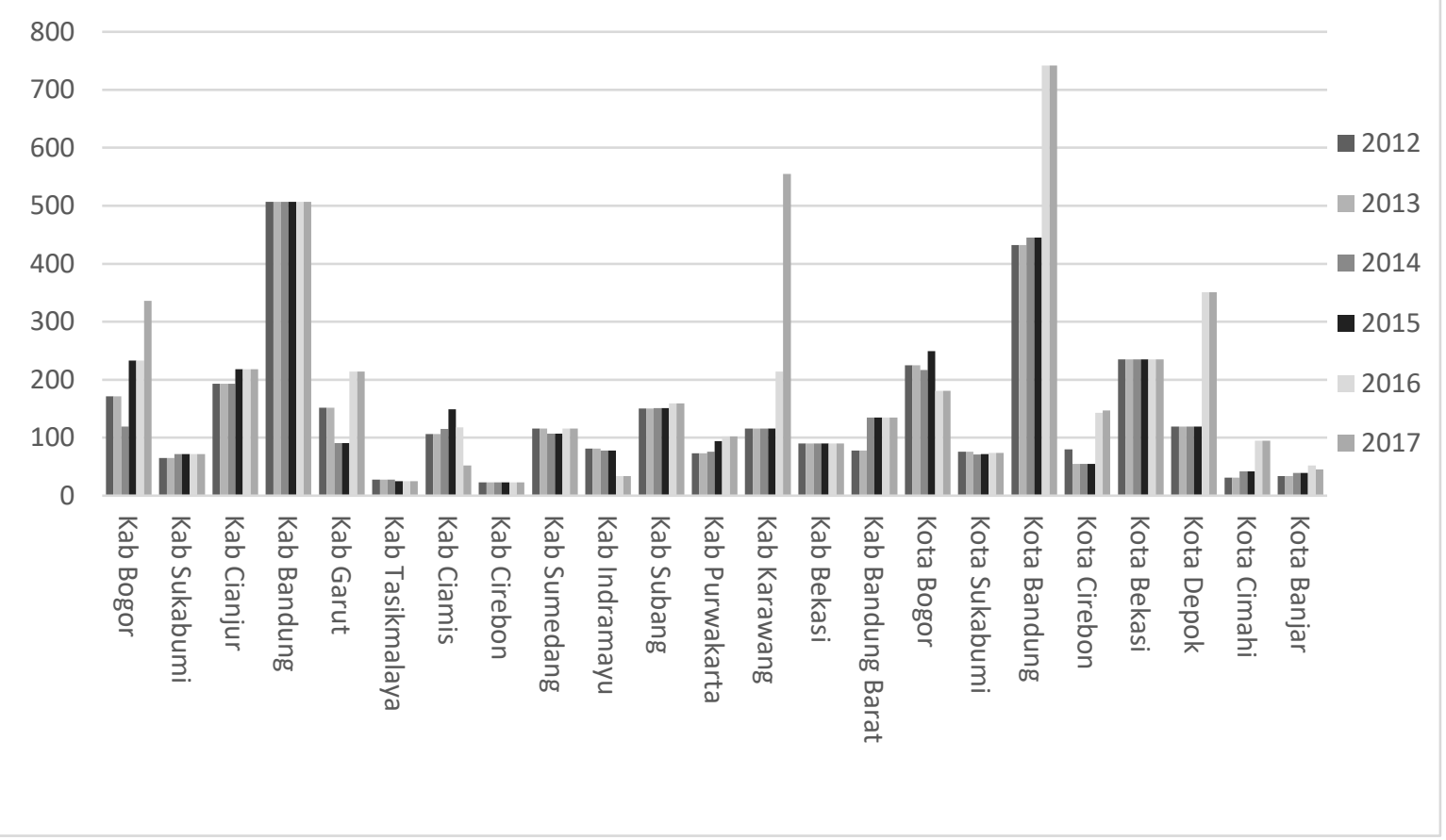

Sumber: Dinas Kebudayan dan Pariwisata

\section{Gambar 5. Jumlah Restoran/Rumah Makan di Kabupaten/Kota di Jawa Barat Tahun 2012-2017}

Seperti ditunjukkan oleh Gambar 5., jumlah restoran/rumah makan di kabupaten/kota di Jawa Barat pada tahun 2012 sampai 2015 tidak mengalami pertambahan yang signifikan. Namun pada tahun 2016 sampai 2017 jumlah restoran/rumah makan di beberapa kabupaten/kota di Jawa Barat mulai mengalami pertambahan yang signifikan. Pada tahun 2012 sampai 2016 jumlah restoran/rumah makan paling banyak terdapat di Kabupaten Bandung, sedangkan pada tahun 2017 ada di Kota Bandung. Wilayah yang memiliki jumkah restoran/rumah makan terkecil adalah 


\section{0| Bina Ekonomi}

Kabupaten Cirebon.

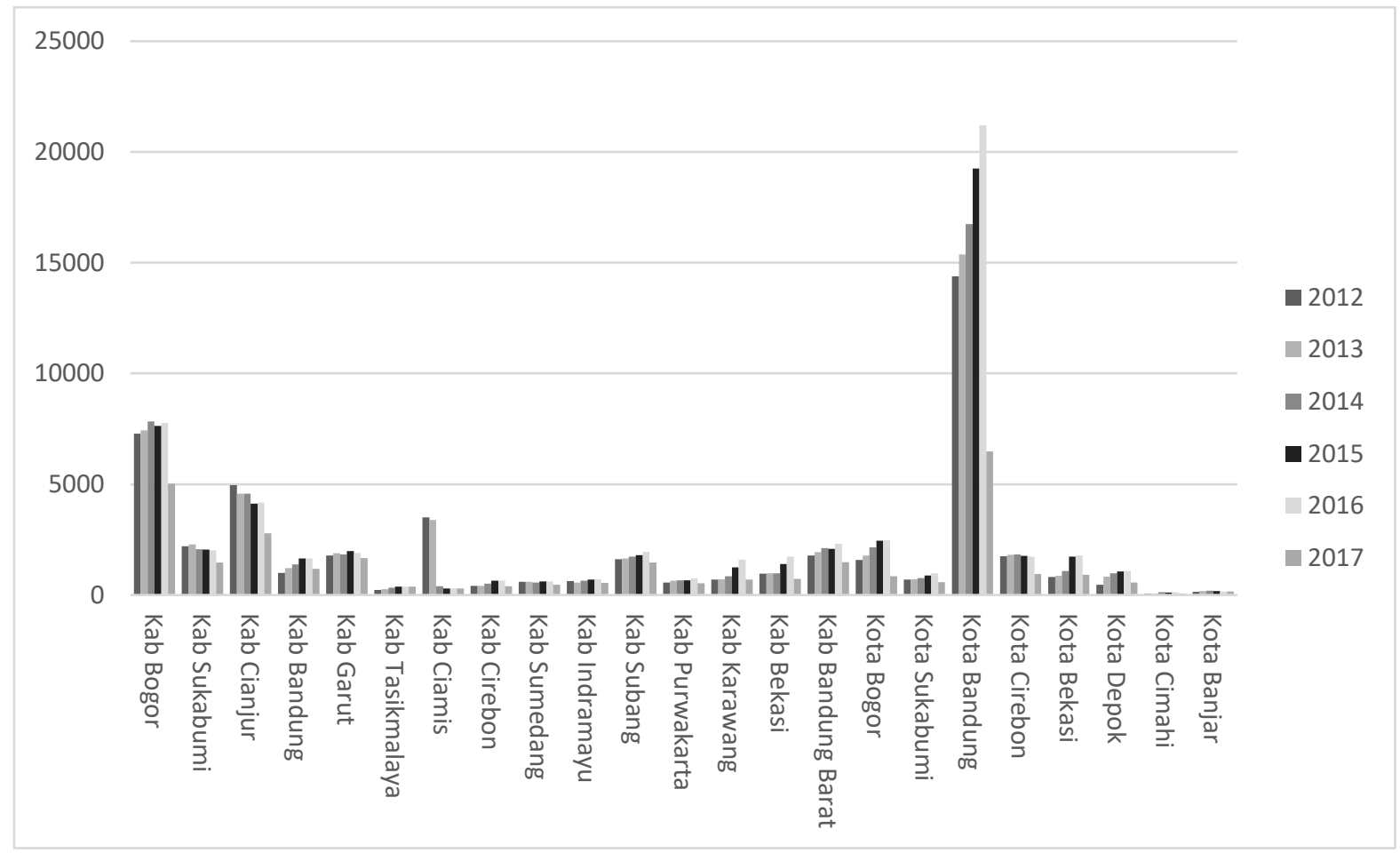

Sumber: Dinas Kebudayan dan Pariwisata

\section{Gambar 6. Jumlah Kamar Hotel di Kabupaten/Kota di Jawa Barat tahun 2012-2017}

Jumlah kamar hotel di kabupaten/kota di Jawa Barat ditunjukkan oleh Gambar 6. Pada tahun 2012 sampai 2017 variabel tersebut cenderung mengalami peningkatan setiap tahunnya, akan tetapi jumlah peningkatannya tidak signifikan. Jumlah kamar hotel di kabupaten/kota di Jawa Barat tidak tersebar secara merata, hanya Kabupaten Bogor dan Kota Bandung yang bisa dikatakan memiliki banyak kamar hotel. Jumlah kamar hotel paling tinggi pada tahun 2012 sampai 2017 ada di Kota Bandung dengan jumlah rata-rata 15.578 kamar. Sementara untuk jumlah kamar paling rendah pada tahun 2012 sampai 2017 terdapat pada Kota Cimahi dengan rata-rata 94 kamar.

Rasio PDRB Sektor Pertanian terhadap PDRB di kabupaten/kota di Jawa Barat digambarkan oleh Gambar 7. Pada tahun 2012 sampai 2017 persentase PDRB sektor pertanian terhadap PDRB total cenderung mengalami penurunan setiap tahunnya. Meskipun demikian, angka rasio ini sangat bervariasi pada tiap kabupaten/kota di provinsi tersebut. Angka rasio terendah terdapat terekam di Kota Bogor, Kota Bandung, Kota Cirebon, Kota Bekasi, dan Kota Cimahi; dengan rasio di bawah satu persen. Sementara itu, empat kabupaten yang masih memiliki angka rasio besar adalah Kabupaten Tasikmalaya, Kabupaten Garut, Kabupaten Cianjur, dan Kabupaten Subang. 


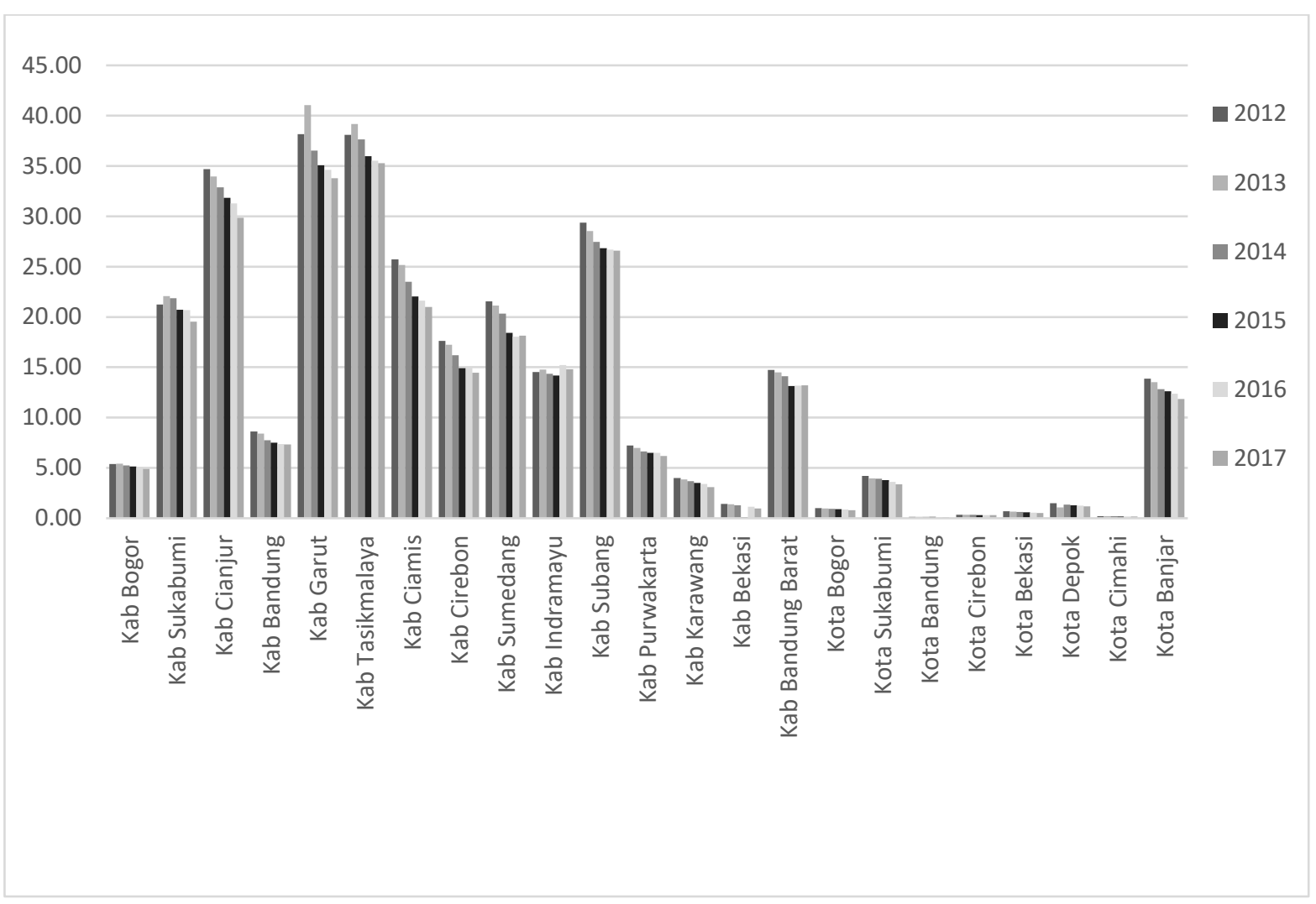

Sumber: Badan Pusat Statistik (BPS)

Gambar 7. Rasio PDRB Pertanian Kabupaten/Kota Jawa Barat Tahun 2012-2017 (Persen)

\section{PEMBAHASAN}

Sebelum melakukan analisis model dan regresi, terlebih dahulu dilakukan uji untuk menentukan pendekatan model yang lebih baik antara pooled least square, fixed effect model, atau random effect model karena penelitian ini menggunakan data panel. Setelah dilakukan pengujian awal, maka akan didapatkan pendekatan mana yang lebih baik dalam penelitian ini. Uji Chow digunakan pada data panel untuk menguji dan memilih metode mana yang lebih baik antara pooled least square dan model fixed effect.. Hasil dari Uji Chow diperlihatkan di Tabel 3.

Tabel 3. Hasil Uji Chow

\begin{tabular}{|c|c|}
\hline Prob $>$ F & Signifikansi $\alpha$ \\
\hline 0,00 & 0,05 \\
\hline
\end{tabular}

Sumber: Hasil pengolahan data

Berdasarkan hasil dari Uji Chow di atas, dapat dilihat bahwa model ini memiliki nilai probabilitas sebesar 0,0000; atau lebih kecil dibandingkan dengan nilai $\alpha$ yaitu sebesar 0,05 . Oleh karena itu dapat diambil kesimpulan bahwa model fixed effect lebih baik digunakan dalam penelitian ini.

Dalam Uji Chow yang dilakukan sebelumnya, dikatakan bahwa Fixed effect adalah model yang lebih baik digunakan dalam penelitian. Akan tetapi untuk memastikan model penelitian maka dilakukan pengujian kembali untuk mengetahui model manakah yang lebih baik antara fixed effect atau random effect menggunakan Uji Hausman. Dari pengujian yang dilakukan, diperoleh hasil yang terlihat di Tabel 4. sebagai berikut: 
Tabel 4. Uji Hausman

\begin{tabular}{|c|c|l|c|l|}
\hline Chi-Squares Statistic & Chi-Squares d.f. & $(\alpha)$ & Chi-squares Tabel & Kesimpulan \\
\hline 8,4019 & 4 & 0.05 & 12,59 & random effect \\
\hline
\end{tabular}

Sumber: Hasil Pengolahan Data

Berdasarkan hasil Uji Hausman menunjukkan bahwa nilai Chi-Squares statistic lebih kecil dibandingkan dengan nilai Chi-Squares tabel, sehingga pengujian yang terbaik menggunakan random effect (Gujarati, 2009).

Berdasarkan berbagai pengujian di atas, estimasi menggunakan pendekatan random effect dengan metode regresi Generalized Least Squares (Robust), hasil ini diperoleh setelah melakukan uji asumsi klasik (uji heteroskedastisitas, uji multikolinearitas, dan uji otokorelasi). Uji Multikolineartitas dilakukan untuk melihat apakah dalam model regresi terdapat korelasi antar variabel independen. Hasil pengujian multikolinearitas dengan matriks korelasi parsial antar variabel independen. Adapun hasil estimasi nilai korelasi antar-variabel bebas ditunjukkan oleh Tabel 5.

Tabel 5. Hasil Uji Multikolinearitas

\begin{tabular}{|c|c|c|c|c|c|}
\hline & LNWISATAWAN & LNRM & LNGOVEX & LNKH & RPDRBR \\
\hline LNWISATAWAN & 1,000000 & 0,447970 & 0,466238 & 0,608323 & 0,117848 \\
\hline LNRM & 0,447970 & 1,000000 & 0,361058 & 0,639164 & $-0,241926$ \\
\hline LNGOVEX & 0,466238 & 0,361058 & 1,000000 & 0,529909 & 0,269752 \\
\hline LNKH & 0,608323 & 0,639164 & 0,529909 & 1,000000 & $-0,035668$ \\
\hline RPDRBP & 0,117848 & $-0,241926$ & 0,269752 & $-0,035668$ & 1,000000 \\
\hline
\end{tabular}

Sumber: Hasil pengolahan data

Pada Tabel 5 terlihat bahwa nilai koefisien korelasi pada setiap variabel independennya tidak ada yang lebih dari 0,8; sehingga dapat disimpulkan bahwa tidak terdapat masalah multikolinearitas pada model ini (Gujarati,2009).

Uji otokorelasi dilakukan untuk melihat apakah dalam suatu model regresi linear ada korelasi antara kesalahan pengganggu pada periode $t$ dengan kesalahan pada periode $t_{-1}$. Dalam melakukan uji otokorelasi, nilai koefisien Durbin-Watson hitung dibandingkan dengan nilai Durbin-Watson dari tabel. Setelah dilakukan estimasi dengan Ordinary Least Squaress, diperoleh nilai Durbin-Watson sebesar 0.52862. Nilai tersebut berada dibawah nilai dL $(1,6476)$. Dengan ini dapat dikatakan terdapat masalah otokorelasi positif pada model ini. Dalam model random effect teknik estimasi yang digunakan adalah GLS maka masalah autokorelasi diasumsikan sudah teratasi (Wooldridge, 2001).

Uji heteroskedastisitas dilakukan dengan tujuan untuk mengetahui apakah dalam model regresi terjadi ketidaksamaan varians dan residual dalam satu observasi ke observasi lainnya. Model yang mengandung masalah heteroskedasitas akan menghasilkan estimasi varians yang salah, yaitu bisa lebih besar atau lebih kecil dari nilai yang sebenarnya. Akan tetapi, karena metode dalam penelitian ini telah menggunakan Random Effect Method dan menggunakan teknik estimasi Pooled Estimated Genelarized Least Squares (Pooled EGLS), maka masalah heteroskedastisitas dalam model ini diasumsikan sudah teratasi seperti yang dikemukakan (Wooldridge, 2001). Hasil estimasi dengan menggunakan random effect ditunjukkan oleh Tabel 6. 
Tabel 6. Hasil Regresi

\begin{tabular}{|l|c|c|}
\hline Variabel dependen: $L n P D R B$ & Koefisien regresi & Standard Error \\
\hline Variabel & 16,763 & $0,276^{* * *}$ \\
\hline Konstanta & 0,001 & 0,009 \\
\hline LnWIS $S_{i t}$ & 0,046 & $0,010^{* * *}$ \\
\hline LnGOVEX & 0,113 & $0,027^{* * *}$ \\
\hline LnRM & 0,023 & 0,014 \\
\hline LnKH & $-0,046$ & $0,007^{* * *}$ \\
\hline RPDRBP & \multicolumn{2}{|c|}{$29,6061^{* * *}$} \\
\hline F-stat & \multicolumn{2}{|l}{} \\
\hline
\end{tabular}

Keterangan: ${ }^{* * *}$ signifikan pada alpha $1 \%$

Uji t-Statistik menunjukkan Variabel Kamar Hotel dan Jumlah Wisatawan tidak mempunyai pengaruh secara statistik. Variabel Pengeluaran pemerintah, Rasio PDRB Sektor Pertanian dan Jumlah Rumah Makan mempunyai pengaruh yang signifikan terhadap Pertumbuhan Ekonomi. Hasil dari uji F menunjukkan bahwa bahwa semua variable independen pada model yang digunakan secara bersama-sama mempengaruhi variable dependennya secara signifikan pada tingkat kepercayaan 99\%.

Nilai koefisien dari jumlah wisatawan terhadap PDRB adalah sebesar 0,001 tidak signifikansi bahkan pada tingkat signifikansi 10\%, sehingga hal ini memperlihatkan bahwa variabel jumlah wisatawan tidak memengaruhi pertumbuhan ekonomi. Hasil ini berbeda dengan penelitian Ige \& Odularu (2010) yang menyatakan jumlah kedatangan wisatawan berpengaruh positif dan signifikan terhadap PDB. Di sisi lain, penelitian Rediteani dan Setiawina (2018) menyimpulkan bahwa pengaruh kunjungan wisatawan terhadap pertumbuhan ekonomi di Kota Denpasar tidak signifikan. Hasil yang tidak signifikan ini bisa disebabkan oleh kontribusi dari sektor pariwisata terhadap PDB yang masih relatif kecil (sekitar 2,9\% antara tahun 2014-2017). Hal ini menunjukkan belum bisa mendongkrak peningkatan PDB secara signifikan. Di samping itu, koefisien yang sangat kecil menunjukkan juga lemahnya peran kunjungan wisatawan dalam meningkatkan PDB. Walau bagaimanapun, tanda positif memberikan dampak yang masih relevan atas peran kunjungan wisatawan terhadap peningkatan perekonomian.

Nilai koefisien dari pengeluaran pemerintah sektor pariwisata terhadap PDRB adalah sebesar 0,046 dan signifikan pada tingkat kepercayaan 99\%. Hal ini memperlihatkan bahwa setiap kenaikan $1 \%$ pada pengeluaran pemerintah sektor pariwisata akan mempengaruhi secara positif terhadap pertumbuhan ekonomi sebesar 0,046\% dengan asumsi ceteris paribus. Hasil ini sesuai dengan penelitian Ardana (2017) yang menyatakan bahwa pengeluaran pemerintah, investasi capital serta pengeluaran wisatawan pada sektor pariwisata berpengaruh positif pada pertumbuhan ekonomi. Belanja modal yang dilakukan pemerintah daerah melalui pengeluaran untuk biaya pemeliharaan yang sifatnya menjaga atau menambah manfaat, serta meningkatkan kuantitas dan kualitas aset dan aksesibilitas dari sektor pariwisata memberikan insentif bagi para wisatawan untuk datang berkunjung dan melakukan pengeluaran yang bisa meningkatkan perekonomian. Peningkatan pengeluaran ini, di lain pihak menjadi stimulus terhadap PDB/PDRB untuk peningkatan pertumbuhan ekonomi.

Nilai koefisien dari jumlah rumah makan terhadap PDRB adalah sebesar 0,113 signifikan pada tingkat kepercayaan 99\%. Hal ini memperlihatkan bahwa setiap kenaikan $1 \%$ pada jumlah rumah makan/restoran akan mempengaruhi pertumbuhan ekonomi sebesar 0,113\% dengan pengaruh yang positif berdasarkan asumsi ceteris paribus. Hasil ini sesuai dengan penelitian Pertiwi, Budhi, dan Saskara (2017) yang menyatakan bahwa jumlah kunjungan wisatawan, 


\section{4| Bina Ekonomi}

tingkat hunian kamar dan jumlah restoran berpengaruh positif dan signifikan tergadap PDRB di kawasan regional Sarbagita. Rumah Makan atau restoran merupakan fasilitas pendukung wisata yang utama, karena merupakan komplemen utama dari sebuah kunjungan wisata. Selain itu, jumlah rumah makan yang relatif banyak di tiap destinasi wisata mempunyai keterkaitan tinggi atas aktivitas masyarakat di sekitar destinasi atau sektor lain dalam perekonomian.

Nilai koefisien dari jumlah kamar hotel terhadap PDRB adalah sebesar 0,023 dan tidak signifikan bahkan pada tingkat signifikansi $10 \%$, sehingga hal ini memperlihatkan bahwa variabel jumlah kamar hotel tidak memengaruhi pertumbuhan ekonomi. Hasil ini sama dengan penelitian Amnar, Muhammad, dan Syechalad (2017) yang menunjukkan bahwa jumlah kamar hotel berpengaruh positif terhadap pertumbuhan ekononomi regional Kota Sabang. Sektor yang merepresentasikan pariwisata, yaitu sektor Penyediaan Akomodasi dan Makan Minum. Kontribusi dari sub-sektor Penyediaan Akomodasi menunjukkan porsi yang hanya 23\%. Hal ini memberikan gambaran atas peran dari kamar hunian yang tidak signifikan.

Nilai koefisien dari rasio PDRB pertanian, peternakan, kehutanan, dan perikanan terhadap PDRB adalah sebesar -0,046 dan signifikan pada tingkat kepercayaan 99\%. Hal ini menunjukkan bahwa setiap penurunan 1\% pada rasio PDRB pertanian, peternakan, kehutanan, dan perikanan terhadap PDRB akan meningkatkan pertumbuhan ekonomi sebesar 0,046\% dengan asumsi ceteris paribus. Dalam pemelitian ini hubungan negatif rasio PDRB pertanian, peternakan, kehutanan, dan perikanan disebabkan oleh penurunan rasio variabel tiap tahunnya pada periode penelitian. Hal ini menunjukkan bahwa pergeseran dari pertanian ke sektor lainnya (salah satunya ke sektor pariwisata) dapat meningkatkan perekonomian.

\section{SIMPULAN}

Beberapa simpulan dapat ditarik dari hasil penelitian ini. Pertama, investasi yang dilakukan pemerintah dalam sektor pariwisata atau mendukung pariwisata merupakan indikator penting dalam mencapai pertumbuhan. Hal ini merupakan salah satu cara untuk mencapai pertumbuhan ekonomi. Pengeluaran pemerintah sektor pariwisata sebagai faktor investasi dalam penelitian ini memiliki pengaruh positif dan signifikan terhadap pertumbuhan ekonomi di kabupaten/kota Jawa Barat pada tahun 2012-2017. Kedua, variabel sektor pariwisata dalam penelitian ini yaitu jumlah restoran/rumah makan berpengaruh positif dan signifikan terhadap pertumbuhan ekonomi. Meningkatnya jumlah restoran/rumah makan juga berpengaruh terhadap pendapatan daerah dalam sektor pajak, dengan meningkatnya pendapatan daerah maka pembelanjaan daerah juga akan meningkat seiring dengan pertumbuhan ekonomi. Terakhir, jumlah wisatawan dan jumlah kamar hotel dalam penelitian ini tidak memiliki pengaruh signifikan terhadap pertumbuhan ekonomi di kabupaten/kota Jawa Barat pada tahun 2012-2017.

\section{DAFTAR PUSTAKA}

Ardana, A.K., (2017), "Pengaruh Sektor Pariwisata terhadap Pertumbuhan Ekonomi Negara Asia Pacific Economic Cooperation (APEC) Periode 2010-2015", Skripsi, Departemen Ilmu Ekonomi Fakultas Ekonomi dan Manajemen, Institut Pertanian Bogor.

Amnar, S., Muhammad, S., \& Syechalad, M. N. (2017). "Pengaruh Pariwisata terhadap Pertumbuhan Ekonomi di Kota Sabang, Jurnal Ekonomi dan Kebijakan Publik Indonesia, $4(1): 13-22$. 
Arghutashvili, Valeri (2018). The Role Of Tourism In Economic Development Of Georgia. Journal of International Management Studies®, pp. 59-64

Ekine; Irene, Data, Onu; Catherine, (2018), "The Impact of Agricultural Output on Economic Growth In Nigeria (1981-2015)", IOSR Journal of Economics and Finance (IOSR-JEF) eISSN: 2321-5933, p-ISSN: 2321-5925. Volume 9, Issue 4 Ver. I (Jul - Aug. 2018), PP 10-14

Gujarati, D. N. (2009). Basic Econometrics (5th Editio). McGraw-Hill.

Ige, C.S.; Odularu, G.O, (2008), "Analysis of the Impact of Tourism on ihe West Africa Economy: a Panel Data Approach", Tourismos: an International Multidiciplinary Journal of Tourism, 3(1):71-90.

Kementerian Keuangan, (2016), Beda Belanja Barang dengan Belanja Modal, Jakarta: Departemen Keuangan Republik Indonesia Direktorat Jenderal Anggaran.

Pertiwi, N.L.G.A, Budhi, IMKS, dan Saskara, I.A.N., (2017), "Pengaruh Jumlah Kunjungan Wisatawan, Tingkat Hunian Kamar, Jumlah Restoran terhadap Pajak Hotel \& Restoran dan PDRB Kawasan Regional Sarbagita di Provinsi Bali", Buletin Studi Ekonomi, 22(1): 10-20

Rediteani, N.M., Setiawani, N.D., (2018), "Pengaruh Jumlah Kunjungan Wisatawan, Lama Tinggal dan Tingkat Hunian Hotel terhadap Pajak Hotel Restoran dan Pertumbuhan Ekonomi Di Kota Denpasar", E-Jurnal EP Unud, 7[1]: 114-133.

Sertoğlu, Kamil; Ugural, Sevin; Bekun, (2017), Festus Victor, 'The Contribution of Agricultural Sector on Economic Growth of Nigeria', International Journal of Economics and Financial Issues, 7(1), 547-552

Sukirno, S. (1997). Pengantar Teori Makro Ekonomi. Jakarta: PT RajaGrafindo Persada.

Wahab, S., (2003), Manajemen Kepariwisataan, Jakarta: Pradnya Paramitha.

Wooldridge, Jefrey M. , (2001), Econometric Analysis of Cross Section and Panel Data, The MIT Press, Cambridge, Massachusetts. 